ORIGINAL ARTICLE

\title{
A Study of Risk Factors Associated with Suspected Blackquarter Outbreaks in Traditionally Managed Cattle in Lusaka Province, Zambia
}

\author{
Mutsuyo KADOHIRA and Kenny L. SAMUI \\ Department of Disease Control, School of Veterinary Medicine, University of Zambia, P.O.BOX. 32379, \\ Lusaka, Zambia
}

(Received 30 July 1997 / Accepted 11 November 1997)

\begin{abstract}
Summary
A case-control study was conducted in Lusaka Province to retrospectively investigate potential risk factors associated with suspected blackquarter outbreaks in traditionally managed cattle in the Province. Data were collected from farms with suspected cases and from apparently blackquarter or blackquarter-like-disease free farms. The data were analyzed using a logistic regression method. Factors that were associated with an increased risk of suspected blackquarter on the study farms were; (i) the total year of experience in rearing cattle and (ii) the use of rivers, streams and dams as the main source of water for cattle.
\end{abstract}

Key words: Blackquarter, Case-control study, Gas gangrene, Traditional cattle, Zambia.

Gas gangrene is a fulminating invasion of living muscular tissue resulting in myonecrosis, oedema and gas formation ${ }^{3)}$. The term includes blackquarter $(\mathrm{BQ})$ and malignant oedema ( $\mathrm{MO})$ in cattle, for which anaerobic, gram positive bacteria, Clostridium chauvoei and $\mathrm{Cl}$. septicum are responsible respectively $2,4,7)$. These organisms are commonly found in soil and in the intestinal tracts of animals ${ }^{2,4,7)}$.

These diseases are characterized by such clinical signs as sudden onset with lameness, fever, depression, followed by serohemorrhagic swellings on the shoulder, neck, back or thigh ${ }^{2,4,7)}$. Death usually occurs $1-2$ days after the onset of these signs ${ }^{2,477}$. However, oedema in MO is more extensive and haemolysis more marked ${ }^{3}$.

$\mathrm{BQ}$ and MO outbreaks occur sporadically in certain areas of the country. Since 1989, the Central Veterinary Research Institute (CVRI) in Zambia has been receiving an ever increasing number of samples from suspected BQ cases $^{11}$. The majority of these samples

Corresponding address: Mutsuyo KADOHIRA Department of Disease Control, School of Veterinary Medicine, University of Zambia, P.O.BOX. 32379, Lusaka, Zambia were from Western Province followed by Southern, Northern and Eastern Provinces ${ }^{1)}$. All were muscle samples taken from foci of serohemorrhagic swellings observed in cattle that had died suddenly. In 1993, 1994 and 1995, the numbers of $\mathrm{Cl}$. chauvoei isolates were 4, 13 and 19 respectively ${ }^{11}$.

In Lusaka Province, suspected BQ outbreaks identified by clinical signs were reported in 1993 and 1994. These outbreaks were controlled by an emergency $\mathrm{BQ}$ vaccination campaign. However, during these outbreaks, neither samples were sent to CVRI nor outbreak investigations conducted. The objective of this study was to retrospectively investigate associations between potential risk factors and the occurrence of suspected $\mathrm{BQ}$ outbreaks using a case-control study.

\section{Materials and Methods}

Study area: The case-control study was conducted in Kafue, Chipapa, Mutamino and Chinyunyu veterinary areas involved in a previous questionnaire survey in Lusaka Province ${ }^{5}$. Lusaka Province is located in the south central part of the Country. Lusaka City, the provincial headquarters, and the national 
capital, is situated in the western part of the Province. Initially the occurrence of suspected $\mathrm{BQ}$ cases was compared among these four study areas, between two areas in each district and between districts using the chi-square test.

Selection of case and control farms: Case and control farms were selected from the 147 farms involved in the previous questionnaire survey mentioned above $^{5)}$. A case was defined as a farm that had experienced mortalities due to suspected $\mathrm{BQ}$ during the 1993 and 1994 outbreaks. A total of 25 farms met this criteria and all were included in the study. A total of 25 control farms were randomly selected from farms involved in the questionnaire survey that did not have any BQ or BQ like cases in 1993 and 1994. First these case farms were stratified by veterinary area and then an equal number of control farms were randomly selected from each veterinary area.

Collection of farm data: This study used the retrospective data on suspected $\mathrm{BQ}$ occurrence collected during the 1995/1996 questionnaire survey mentioned above ${ }^{5)}$. Information on disease control method, presence of wild animal, water source and characteristics of farmers were obtained as categorical risk factors. Family size, herd size, farm size and cattle rearing experience were recorded as non-categorical risk factors, i.e., in continuous values.

Statistical analysis: The farm was the unit of analysis and all measurements were made at the farm - level. In the first stage, univariable analysis was applied. The measure of association between possible risk factors and the occurrence of suspected $\mathrm{BQ}$ was examined for each factor individually. Categorical factors were evaluated for statistical significance using a chi-square test for independence. Means and standard deviations for non-categorical variables with normal distributions and homogeneous variances between the case and the control groups were tested for their statistical significance by means of a oneway analysis of variance. The Kruskal-Wallis test was used for any non-categorical variable which did not have homogeneous variances. In the second stage, multivariable analysis was employed. Those risk factors having significant association $(\mathrm{p}<0.10)$ with suspected $\mathrm{BQ}$ status in the univariable analysis were evaluated using a multiple logistic regression model.
Dependent variable of the model in this studyis asingle binary value, ie., $\mathrm{Y}=1$ if a farm is a case farm. The multiple logistic regression model can deal with such a binary dependent variable and examine the relationship between case farms and several farmlevel risk factors. Regression coefficients are interpreted as odds ratios. This model was fitted using Statistical Package for Social Scientists (SPSS) software (SPSS Inc., Chicago, USA). Factors had to have a $\mathrm{P}$ value of 0.05 or less to remain in the model. Following the fitting of the main effects model, all two- way interactions between significant main effects were added to the model and tested for significance. Odds ratios and their $95 \%$ confidence interval were calculated.

\section{Results}

Descriptive analysis: Table 1 displays the frequency of occurrence of suspected $\mathrm{BQ}$ cases by study area and district in the Province. The occurrence varied among the four study areas $(\mathrm{p}<0.01)$, but was similar between areas in each district $(p>0.1)$. The frequency of occurrence between districts was different $(\mathrm{p}<0.01)$.

Univariable analysis: Table 2 shows the names, descriptions and distribution of categorical risk factors. Distribution of risk factors except water source were similar between case and control farms. Means, standard deviations (SDs) and ranges of noncategorical risk factors for case and control farms are shown in Table 3. In relation to total years of cattle rearing, significant difference was observed between case and control farms. Two risk factors, water source and cattle rearing experience in years, were then offered to enter in a multiple logistic regression model.

Multivariable analysis: The factors significantly associated $(\mathrm{p}<0.05)$ with a farm having an increased risk of suspected $\mathrm{BQ}$ outbreak were; (i) the total year of cattle rearing experience of farm owner and (ii) the use of rivers, streams and dams as the main water source for cattle (Table 4). Adding the interaction term between these variables did not produce a significant likelihood ratio statistics. An odds ratio estimates likelihood that a farm with a given factor will have suspected $\mathrm{BQ}$ cases relative to a farm 
without that factor. For example, a farm that use of a river, stream or dam as the main water source for cattle was 6 times as likely to have suspected BQ cases as a farm that use a borehole after controlling for the natural log of the total year of cattle rearing experience of farmers (LNYEARS). For non categorical risk factors, the odds ratio provides an estimate of the risk of having suspected $\mathrm{BQ}$ relative to an incremental change in that factor. For example of LNYEARS, a farm that has 20 years experience in cattle rearing was 3 times as likely to have suspected $\mathrm{BQ}$ cases as a farm with 7 years experience after controlling for water source.

\section{Discussion}

In this study, case control techniques were used for screening risk factors associated with suspected $\mathrm{BQ}$ outbreaks in Lusaka Province. The advantage is that

Table 1. The frequency of occurrence of suspected BQ cases in the four study areas in Lusaka Province, Zambia, 1993-94

\begin{tabular}{cclc}
\hline Study area & Suspected BQ & District & Suspected BQ \\
\hline Kafue & $23 \%(8 / 35)$ & Kafue & $27 \%(20 / 74)$ \\
Chipapa & $31 \%(12 / 39)$ & Kafue & \\
Mutamino & $6 \%(2 / 32)$ & Chongwe & $7 \%(5 / 73)$ \\
Chinyunyu & $7 \%(3 / 41)$ & Chongwe & \\
\hline Total & $17 \%(25 / 147)$ & & \\
\hline
\end{tabular}

Table 2. The names, descriptions and distribution of categorical risk factors by suspected BQ farm status ( 25 case and 25 control farms) in Lusaka Province, Zambia, 1993-94 (risk factor data collected in 1995-96)

\begin{tabular}{|c|c|c|}
\hline Description & Cases & Controls \\
\hline \multicolumn{3}{|c|}{ Presence of wild animal in the vicinity of farms } \\
\hline yes & 9 & 6 \\
\hline no & 16 & 19 \\
\hline \multicolumn{3}{|l|}{ Water source ${ }^{a)}$} \\
\hline borehole (artificial) & 2 & 8 \\
\hline stream/river/dam (natural source) & 23 & 17 \\
\hline \multicolumn{3}{|l|}{ Disease control } \\
\hline regularly applied & 10 & 13 \\
\hline rarely or none & 15 & 12 \\
\hline \multicolumn{3}{|l|}{ Female headed farm } \\
\hline yes & 1 & 2 \\
\hline no & 24 & 23 \\
\hline \multicolumn{3}{|l|}{ Cash crop production } \\
\hline engaged & 12 & 11 \\
\hline no & 13 & 14 \\
\hline \multicolumn{3}{|l|}{ Non-family employee } \\
\hline present on farm & 1 & 5 \\
\hline none & 24 & 20 \\
\hline \multicolumn{3}{|c|}{ Involved in another business other than farming } \\
\hline yes & 2 & 5 \\
\hline no & 23 & 20 \\
\hline \multicolumn{3}{|l|}{ Educational level of farm owner } \\
\hline never been to school & 4 & 7 \\
\hline at least a few years in School & 21 & 18 \\
\hline
\end{tabular}

a) $\mathrm{P}<0.10$ : offered to multiple logistic regression model 
we were able to gain information by the case-control approach to indicate what bacterial samples should be collected.

The frequency of occurrence of suspected BQ outbreaks in Kafue district was much higher than in Chongwe district. In Kafue district, the Kafue flat is flooded during the rain season and most farmers in Kafue veterinary area use the Kafue river as the main source of watering for their cattle. Some practice seasonal grazing and leave herds on the flat in the entire dry season. $\mathrm{BQ}$ and $\mathrm{MO}$ are soil-borne infections, and survived best in soils rich in organic matter and water holes ${ }^{2,4,7)}$. The spores are extremely resistant and may remain infective for many years. Likewise, certain farms and pastures may remain potentially dangerous. Floods could increase cattle's exposure to such contaminated soil ${ }^{7)}$. Similar situations might have occurred at dams or streams in other parts of the Province prior to outbreaks in 1993 and 1994.

The strength of association between a factor and a disease is known as relative risk $(\mathrm{RR})^{6)}$. Since the rates of disease in the exposed and unexposed groups are unknown, RR cannot be calculated in case control studies $^{6)}$. Instead, odds ratio can be used and interpreted exactly the same as RR. When odds ratio is equal to 1 , there is no association between the factor and the disease. The greater the departure of the odds ratio from 1, i.e., either larger or smaller, the stronger the association between the factor and the disease. The multiple logistic regression model is useful for estimating odds ratio as regression coefficient after controlling for all other risk factors, including interaction terms and non-categorical factors.

Water source and total years of cattle rearing experience were risk factors associated with the occur

Table 3. The names, descriptions and distribution of non-categorical risk factors by suspected BQ farm status ( 25 case and 25 control farms) in Lusaka Province, Zambia, 1993-94 (risk factor data collected in 1995-96)

\begin{tabular}{lll}
\hline & $\begin{array}{l}\text { Cases } \\
\text { Mean (SD) } \\
\text { Range }\end{array}$ & $\begin{array}{l}\text { Controls } \\
\text { Mean (SD) } \\
\text { Range }\end{array}$ \\
\hline $\begin{array}{l}\text { Family size } \\
\text { total number of people living on farm }\end{array}$ & $\begin{array}{l}14.6(10.2) \\
5-45\end{array}$ & $\begin{array}{l}11.9(9.0) \\
5-51\end{array}$ \\
$\begin{array}{l}\text { Herd size } \\
\text { total number of cattle in farm }\end{array}$ & $17.9(17.2)$ & $11.8(9.1)$ \\
$\quad 3-63$ & $2-44$ \\
Farm size (acres) & $15.3(18.5)$ & $19.1(29.6)$ \\
total size of farming areas & $3-80$ & $1-150$ \\
$\quad$ & $28(19.7)$ & $15.6(11.0)$ \\
Cattle rearing (years) ${ }^{\text {a) }}$ & $4-80$ & $1-41$ \\
\hline total length of owners' experience & & \\
\end{tabular}

a) $\mathrm{P}<0.10$ : offered to multiple logistic regression model following transformation to log scale.

Table 4. Odds ratio from the final logistic regression model of risk factors associated with the occurrence of suspected BQ cases in Lusaka Province, Zambia, 1993-94 (risk factor data collected in 1995-96)

\begin{tabular}{lcccc}
\hline Term & Coefficient & Odds ratio & 95\%confidence interval \\
\hline Intercept & -4.4 & & & \\
LNYEARS $^{\mathrm{a})}$ & 1.1 & 3.0 & 1.4 & 6.6 \\
WATER $^{\mathrm{b}}$ & 1.8 & 6.0 & 1.0 & 35.3 \\
\hline
\end{tabular}

a) The natural log of the total year of cattle rearing experience of farmers. b) Farms that use rivers, streams and dams as the main source of water for cattle 
rence of suspected $\mathrm{BQ}$ cases. Water itself, of course, would not be the source of reserving microbiological agents, but the underlying soil. When the water level is very low in dams or streams, cattle are likely to ingest soil at the time of watering. In 1993 and 1994, there was severe drought in the Province and with the resultant deficiency in the water supply, cattle could have been exposed to contaminated soil during this period.

Longer cattle rearing experience usually provides farmers with more knowledge on disease control. The possible association between water source and LNYEARS was investigated because early established farmers tend to have occupied farming areas near such water sources as rivers and streams. However, farming experience and water source were not correlated. One potential link between farming experience and $\mathrm{BQ}$ occurrence is that farming experience is a proxy of length of time cattle have been kept. Farms having cattle for longer periods would have higher risk of soil contamination from previous $\mathrm{BQ}$ occurrence.

The study result indicated that soil samples should be collected from water sources for providing more evidence on the association between water sources and suspected $\mathrm{BQ}$ outbreaks. From the foregoing, there is a need for bacterial diagnosis of $\mathrm{BQ}$-like diseases in order to gain an insight into the magnitude of the disease. The latter would form a basis for further and more refined studies especially regarding the economics of $\mathrm{BQ}$ vaccinations. When the risks and vaccination costs are known, it would be possible to determine the benefits of vaccinations and thus be able to convince the farmers to have their animals regularly vaccinated.

\section{Acknowledgements}

We are grateful for Dr. Lemba for his assistance in SPSS programming. Japan International Cooperation Agency provided the transportation.

\section{References}

1 ) Anonymous. 1989 - 1995 CVRI Annual reports, Department of Animal Production and Health, Ministry of Agriculture, Lusaka.

2 ) Blood, D.C., Radostits,O.M., and Henderson, J.A. 1983. Diseases caused by bacteria II. pp.536-556. In: Veterinary Medicine, 6 th ed., Bailliere Tindall, London.

3 ) Edelstern, R.M., Gourlay, R.N., Lawson, G.H.K., Morrow, A.N., and Ramachandran,S. 1990. Diseases caused by bacteria. pp.33-103. In: Handbook on Animal Diseases in the Tropics, 4th ed. (Sewell, M.M.H. and Brocklesby, D.M. eds.), Bailliere Tindall, London.

4 ) Howe, D.L. 1981. Miscellaneous bacterial diseases. pp.418-422. In: Infectious Diseases of Wild Mammals, 2nd ed. (Davis, J.W., Karstad, L.H., and Trainer, D.O. eds.), The Iowa State University Press, Ames.

5 ) Kadohira, M., Samui, K.L., and Mlangwa, J.E.D. 1996. The health and productivity of traditionally managed cattle in Lusaka Province, Zambia: results of a questionnaire survey. Zambian J.of Vet. Sci. 1: 11-20.

6 ) Martin, S.W., Meek, A.H. and Willeberg, P.1987. Veterinary Epidemiology: Principles and Methods, Iowa States University Press, Ames.

7 ) Selman, I.E. 1981. Blackleg and malignant oedema. pp.247-254. In: Diseases of Cattle in the Tropics ( Ristics, M. and McIntyre, I. eds.), Martinus Nijhoff Publishers, The Hague. 


\title{
本文要約（原著）
}

\section{ザンビア国ルサカ州で発生した気腫疽を疑われた死亡例に関連する 危険因子の研究}

\author{
門平睦代, Kenny L. SAMUI \\ ザンビア大学獣医学部
}

1993年から94年にかけてザンビア国ルサカ州全域の伝統農家の多数の牛が死亡した。発生状況から気腫疽が疑われ た。緊急にワクチン接種が行われ, その後は死亡例の報告は見られなかった。当時, 細菌学的診断も含めて発生原因 に関する調査は何も実施されなかった。そこで過去にさかのぼり, 患畜対照研究を行い, 気腫疽が原因と疑われた死 亡例があった農家群と, 気腫疽や気腫疽に類似した症例がなかった農家群の 2 つのグループから, 家畜飼育方法など の危険因子と考えられるデー夕を集めた。そして，これらの危険因子と死亡例があった農家との間に関連性があるの かについて統計学的解析をした。牛飼育総経験年数と川や貯水池などの自然水系を牛の飲料水として使っているとい う， 2 つの危険因子が疾病の発生と関連していることが明らかになった。この結果は, 気腫疽発生に関して, どの農 家がリスクが高いか，またどこから土壌サンプルを採取すべきかなど土堙污染地域を見つける調査指標として，有効 な情報となりうる。 